\title{
O PREÇO DO PROGRESSO HUMANO: A PROBLEMÁtICA AMBIENTAL ARTICULADA AO PROCESSO DE URBANIZAÇÃO
}

\author{
Marcelo Penna da Silva ${ }^{1}$ \\ Victor Pereira de Sousa ${ }^{2}$
}

\begin{abstract}
Resumo: O presente trabalho busca uma análise baseando-se na urbanização sem planejamento - ou em sua ineficiência - sob uma ótica ambiental, onde a maioria das ditas "catástrofes", são nada mais nada menos que reflexo do - não - planejamento urbano. Analisando-se a evolução do agir do Homem no meio, perante um olhar crítico, é possível constatar problemas da atualidade, como poluição, desmatamento, crescimento desenfreado de cidades, a fim de propiciar uma pseudo-evolução social. Assim, acerca de metodologia de gabinete, o presente trabalho visa uma análise ambiental articulada ao processo de urbanização e da problemática contemporânea que abarca nosso cotidiano em linhas socioambientais do progresso humano.
\end{abstract}

Palavras-chave: Urbanização; Planejamento; Poluição. 1 Graduando em Geografia/Universidade do Estado do Rio de Janeiro - UERJ, Brasil. E-mail:
celo_penna2@hotmail.com.
2 Graduando em Geografia/Universidade do Estado do Rio de Janeiro - UERJ, Brasil. E-mail:
victordesousa@outlook.com.br. 